\title{
Some aspects of the ecology of the Indian Giant Squirrel Ratufa indica (Erxleben, 1777) in the tropical forests of Mudumalai Wildlife Sanctuary, southern India and their conservation implications
}

\author{
Nagarajan Baskaran ${ }^{1}$, S. Venkatesan ${ }^{2}$, J. Mani ${ }^{3}$, Sanjay K. Srivastava ${ }^{4}$ \& Ajay A. Desai ${ }^{5}$ \\ 1,2,3,5 Bombay Natural History Society, Bear Bungalow, Kargudi, The Nilgiris, Tamil Nadu 643211, India \\ ${ }^{1}$ Present Address: Asian Nature Conservation Foundation, Innovation Centre, Indian Institute of Science, Bengaluru, Karnataka \\ 560012, India \\ ${ }^{4}$ Tamil Nadu Forest Department, Panagal Building, No. 1 Geenis Road, Saidapet, Chennai, Tamil Nadu 600015, India \\ ${ }^{5}$ Present Address: BC 84 Camp, Belgaum, Karnataka 590001, India \\ Email: ${ }^{1}$ baskar@ces.iisc.ernet.in (corresponding author), ${ }^{4}$ sks2700@yahoo.co.in, ${ }^{5}$ ajayadesai.1@gmail.com
}

Date of publication (online): 26 July 2011 Date of publication (print): 26 July 2011 ISSN 0974-7907 (online) | 0974-7893 (print)

Editor: Renee Borges

Manuscript details:

Ms \# 02593

Received 01 October 2010

Final received 29 January 2011

Finally accepted 09 July 2011

Citation: Baskaran, N., S. Venkatesan, J. Mani, S.K. Srivastava \& A.A. Desai (2011). Some aspects of the ecology of the Indian Giant Squirrel Ratufa indica (Erxleben, 1777) in the tropical forests of Mudumalai Wildlife Sanctuary, southern India and their conservation implications. Journal of Threatened Taxa 3(7) 1899-1908.

Copyright: (c) Nagarajan Baskaran, S Venkatesan, J. Mani, Sanjay K. Srivastava \& Ajay A. Desai 2011. Creative Commons Attribution 3.0 Unported License. JoTT allows unrestricted use of this article in any medium for non-profit purposes, reproduction and distribution by providing adequate credit to the authors and the source of publication.

Author Detail: see end of this article.

Author contribution: The first author designed and conducted the present study with technical support from the fourth and fifth authors. The second and third authors helped the first author partly in field data collection.

Acknowledgement: We acknowledge the Forest Department of Tamil Nadu for suggesting and funding the study. We thank Mr. J.C Daniel, Honorary Secretary, Bombay Natural History Society for his encouragement and support during the project.

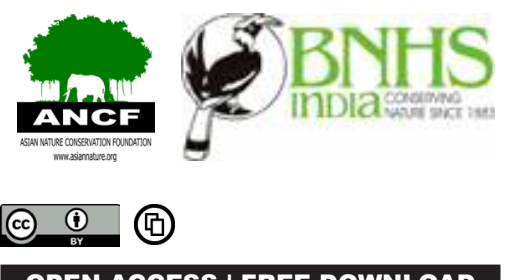

Abstract: The Indian Giant Squirrel Ratufa indica, an endemic species to India, is widely distributed from the evergreen to moist and dry deciduous forests of Western and Eastern Ghats and the central Indian hills. We studied its population distribution, activity, feeding, ranging and nesting behaviour across three major habitats in the tropical forests of Mudumalai Wildlife Sanctuary, southern India, during 1998-2000 to manage the species effectively. Extensive survey of the three major habitats-tropical moist, dry deciduous and dry thorn-in the sanctuary shows that its distribution is continuous in moist and dry deciduous forests with good canopy contiguity and patchy along riverine areas in dry thorn and dry deciduous forests with sparse trees and broken canopy. Density estimates using 55 direct sightings from $199 \mathrm{~km}$ line transects show a mean of 2.9 ( \pm 0.313 ) squirrels $/ \mathrm{km}^{2}$. Daylight activity and feeding patterns assessed through 24,098 minutes of focal sampling reveal that animals feed and rest equal amounts of time. The diet constitutes seeds, bark, petioles, leaves and fruits from 25 plants, with Tectona grandis as the principal food source $(41 \%)$. Its home range size varied from 0.8-1.7 ha with a mean of 1.3ha. Nesting characteristics assessed through 83 nests surveyed along $54 \mathrm{~km}$ transects showed that the squirrel uses 15 of the 33 tree species found, with higher preference to Schleichera oleosa and Mangifera indica. Nest trees are significantly larger in height, gbh and canopy contiguity than nearest non-nest trees, which are attributed to better protection and escape from predators. Maintenance of diverse natural habitats and reduction in anthropogenic pressure are measures suggested for the conservation of giant squirrel populations in the study area.

Keywords: Breeding, diet, ecology, feeding, population, ranging, Ratufa indica.

\section{INTRODUCTION}

The Indian Giant Squirrel Ratufa indica is a large arboreal squirrel endemic to India (Image 1). The species is widely distributed in peninsular India (Abdulali \& Daniel 1952; Corbet \& Hill 1992) from the evergreen to moist and dry deciduous forests of Western (Ramachandran 1988, 1992; Rout \& Swain 2005), and Eastern Ghats (Kumara \& Singh 2006) and central Indian Hills (Agarwal \& Chakraborty 1979). The species is listed as Least Concern in Red List of IUCN (Rajamani et al. 2009) and of Schedule I (Part I) of the Indian Wildlife Act (1972). The species, like many other squirrels of its genus, is a top canopy dweller, which occasionally comes to the ground (Ramachandran 1988), mostly to overcome breaks in canopy continuity. The species mostly feeds on seeds, leaves, flowers and bark from trees. It is a solitary living species, constructs globular nests or dreys with leaves and twigs (Borges 1989; Thorington \& Cifelli 1989; Ramachandran 1992). Considering its arboreal nature and dependence on 


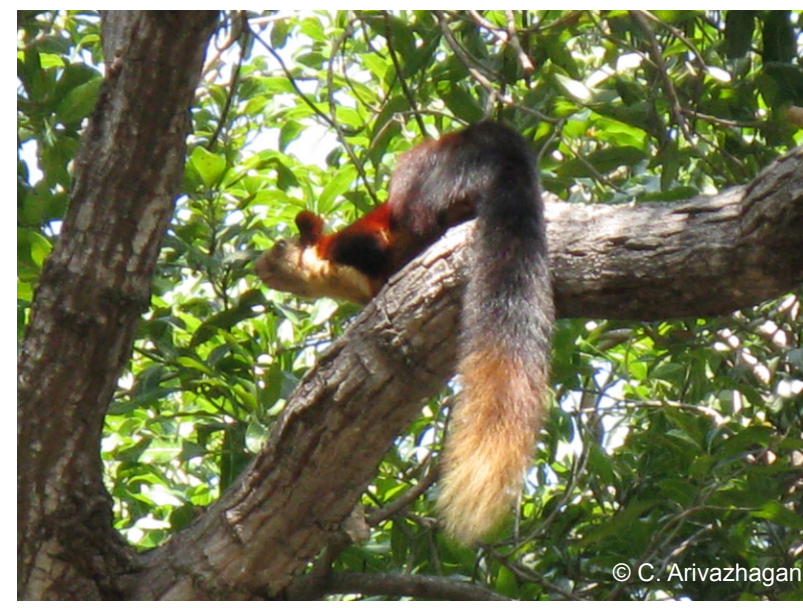

Image 1. The Indian Giant Squirrel Ratufa indica

trees for food, shelter and movement, it is apparent that the composition of tree species and structural attributes of the forests play a major role in the use of the habitat by the giant squirrel (Borges 1989; Ramachandran 1992; Datta \& Goyal 1996). Understanding the species distribution and its resource requirements are essential for its long-term conservation plans. Ratufa indica centralis is very common in parts of Nilgiri Biosphere Reserve; yet no published ecological data essential for the management of the species is available from this region. This paper addresses the basic ecological aspects such as population, factors influencing its distribution, foraging, nesting and ranging behaviour of the Indian Giant Squirrel in the tropical forests of Mudumalai Wildlife Sanctuary, which is part of the Nilgiri Biosphere Reserve.

\section{METHODS}

Study area: The study was carried out in Mudumalai Wildlife Sanctuary (presently a Tiger Reserve) during 1998-2000. The sanctuary lies between $11^{0} 32^{\prime}-11^{\circ} 45^{\prime} \mathrm{N}$ and $76^{\circ} 20^{\prime}-76^{\circ} 45^{\prime} \mathrm{E}$, and is a part of the Nilgiri Biosphere Reserve. It is bounded on the north by Bandipur Tiger Reserve, to the west by Wayanad Wildlife Sanctuary and to the south and east by Nilgiri North Forest Division. The terrain is undulating with an average elevation of 900-1000 m. Only the Moyar River and a few bigger streams that drain into it are perennial. Additionally, several large manmade water holes act as water sources during the dry season for wild animals. The study area has two wet seasons (the southwest monsoon: May-August and northeast monsoon: September-December) and a dry season (January-April). The rainfall has a marked east-west gradient with eastern areas receiving 600$800 \mathrm{~mm}$ of precipitation annually and the western regions $1800-2000 \mathrm{~mm}$. Temperature ranges from $8^{\circ} \mathrm{C}$ in December to $35^{\circ} \mathrm{C}$ in April (Baskaran 1998). The vegetation follows a gradient similar to the rainfall, with dry thorn forests dominating the eastern side of the sanctuary followed by dry deciduous short grass and dry deciduous tall grass forests in the middle, and moist deciduous forests to the western side. There are also a few patches of semievergreen forest along the western side of the sanctuary. We selected four sites for detailed behavioural data collection on giant squirrels in four different habitats, which include moist deciduous forest, a dry stream in the dry deciduous forest, a riverine habitat and a teak plantation.

Distribution pattern: We mapped the distribution of giant squirrel based on the presence and absence of squirrel direct sightings and their nests walking along 65 transects laid across the sanctuary covering all major and microhabitats used for density estimation of squirrel and their nests. In all the major habitats, an effort was made to sample the riverine (along river and stream) microhabitats as they are distinct from surrounding areas in terms of tree species composition and canopy contiguity, especially in the dry deciduous and dry thorn forest.

Population density: We used the line transect method (Burnham et al. 1980) to estimate population density. In total, 65 transects with length varying from 2-4 km, laid systematically covering all the habitats and microhabitats across the sanctuary were sampled once partly (16 transects) during May 1998 and rest in May 1999. The transects were walked during morning (0600-1000 hr) or evening (1600-1800 hr) and at every sighting of squirrel we recorded the perpendicular distance, using range finders and group size of the squirrel. In total, 55 sightings were recorded from $199.3 \mathrm{~km}$ line transect walk. Mean group (cluster) size $(\mathrm{G})$ and its standard error (SE) was estimated based on data where complete counts of individuals were obtained on transects. Population density was estimated using distance-sampling techniques following the software DISTANCE version 6.0 (Buckland et al. 2004; Thomas et al. 2005). Grouping the data into $10-\mathrm{m}$ perpendicular intervals, 
squirrel cluster density (C) and its SE was estimated evaluating different models of detection probability, viz. uniform, half-normal and hazard-rate with three series adjustment terms and used the minimum Akaike Information Criteria (AIC) as the standard model selection procedure to select the best model for estimating density. Individual squirrel density (D) was arrived at multiplying the mean group size (G) by the squirrel cluster density (C). Standard error of individual squirrel density (seD) was calculated using standard error of cluster density $(\mathrm{seC})$ and standard error of mean group size (seG) using Goodman's (1960) formula: $(\mathrm{seD})=\mathrm{C}(\mathrm{seG})+\mathrm{G}(\mathrm{seC})-(\mathrm{seC})(\mathrm{seG})$ and used the same to work out the $95 \%$ confidence limit of individual squirrel density.

Activity pattern and feeding: Data on activity and feeding were recorded through direct observation using the focal animal sampling method (Altmann 1974). Observations were made for a period of two days (six hours per day: either $0600-1200 \mathrm{hr}$ or $1200-1800 \mathrm{hr}$ ) per month from each site. Daylight hours from 0600 to $1800 \mathrm{hr}$ were divided into 12 one-hour blocks for sampling and an attempt was made to sample each one-hour block at least once a month. Focal sampling was made at $15 \mathrm{~min}$ interval (of $10 \mathrm{~min}$ observations and 5min break). Thus, observations started at nearest $1^{\text {st }}$ or $15^{\text {th }}$ or $30^{\text {th }}$ or $45^{\text {th }}$ minute of any hour of sighting time. At every focal sampling, the subject was continuously observed for a period of one minute and recorded its activity (feeding, resting, moving and others: inter and intraspecific activities, drinking/ water licking (from tree holes and leaf surfaces), urination, defecation and nest construction) at every minute interval for a period of 10 minute; in case of feeding, plant species and parts consumed. While on feeding, the squirrel often goes to the tip of branches and collects (cuts) the food items (fruits, seeds, leaves etc) with its mouth and moves to the thick horizontal branches by holding the food items mostly in the mouth and some time in the forelimb, where branch is stronger and it is convenient for the squirrel to sit and feed. In the present study, such movements over small distances within the same tree while on feeding (with the food materials in mouth or forelimb) were clubbed with feeding activity. Time spent on various activities and feeding of different plant species was computed season-wise for each habitat separately from the 12 month observations.
Nesting characteristics: Nest site characteristic features were collected along 25 transects covering three major habitats in the sanctuary. For each nest located along the transect, we have recorded variables such as tree species used for nesting, their height, girth at breast height $(\mathrm{GBH})$, number of main branches, canopy heights, canopy contiguity on all four directions, height of nest from ground. Squirrels jump from one tree to another and gaps between trees of $<10$ foot and with larger branches at the edge, which the squirrel use to jump, were also considered as continuous canopy. In addition, to compare the characteristic features of nest trees with non-nest trees, data on tree species composition, presence or absence of giant squirrel nest in each tree and variables recorded for nesting trees were collected along the transect at $100 \mathrm{~m}$ interval using 'point center quadrat' method.

Home range size: Data on ranging behaviour was collected for four squirrels observed for feeding observations from three habitats over a period of 5-8 months. The sighting location and maximum distance moved from nesting trees on the day when the squirrel was followed for feeding observation were marked on the topo sheet. The home (annual) range was estimated connecting the outermost locations following minimum polygon method (Jennrich \& Turner 1969).

\section{RESULTS AND DISCUSSION}

Distribution pattern: Direct sighting of giant squirrel and its nesting across three major habitats showed its distribution to be continuous in moist deciduous forest on the western side of the sanctuary (Fig. 1) and patchy in dry thorn forest on the eastern side, where it is largely restricted to the streams representing riverine habitat supported by large trees with better canopy contiguity. On the other hand, in the dry deciduous forest with large trees and good canopy contiguity (around the central areas of the sanctuary), its distribution is more widespread, but in areas of sparse/stunted trees with broken canopy interspersed with savanna grasslands or extensive Shorea talura regeneration, it is restricted to stream microhabitat similar to that of dry thorn forest. In general, Indian giant squirrel appears to be adapted to evergreen and moist deciduous habitats, while extending into closed canopy areas of dry deciduous forest. Its use 


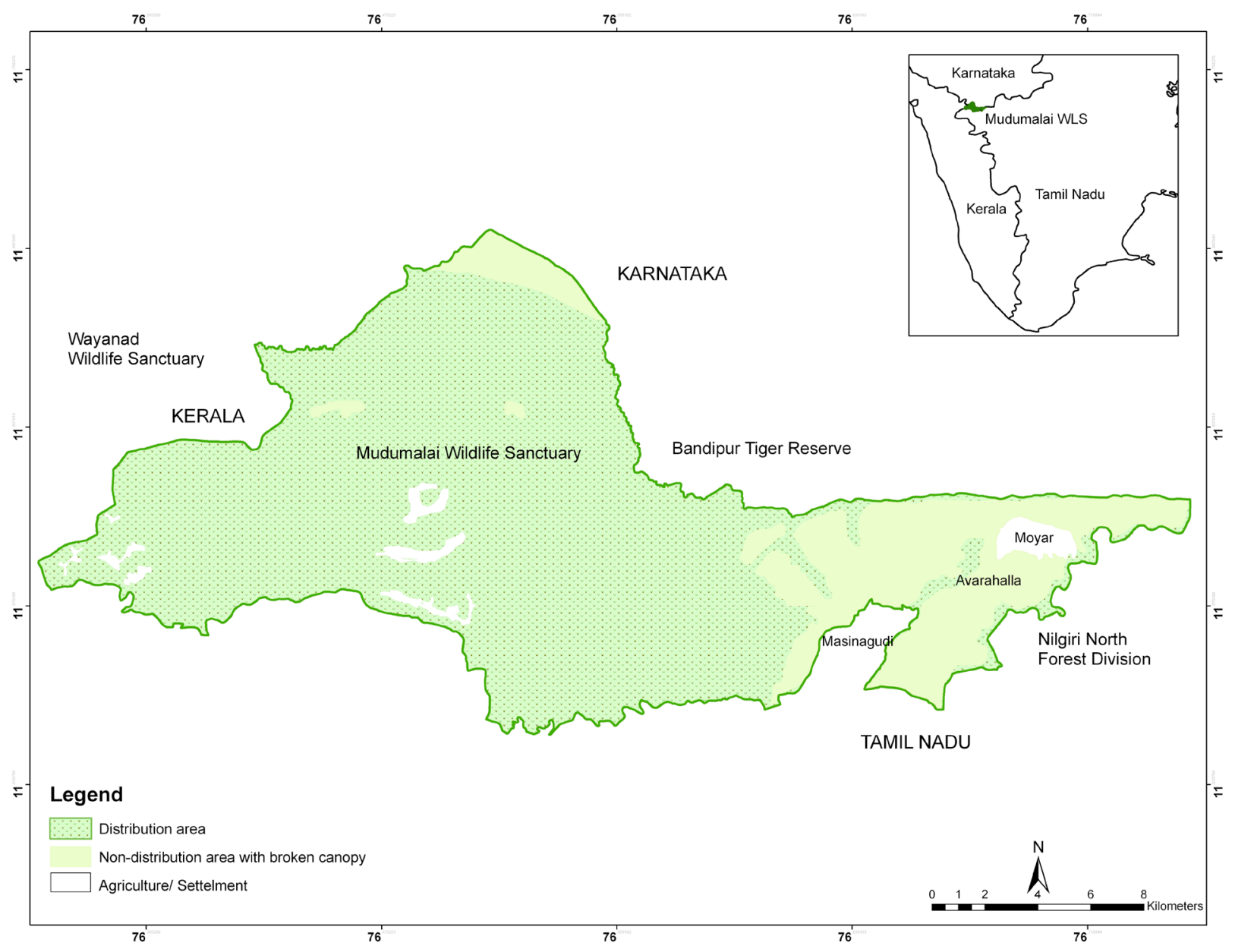

Figure 1. Map showing the distribution of Indian Giant Squirrel Rattufa indica in Mudumalai Wildlife Sanctuary, India

of closed canopy dry deciduous forest appears to the limit of its ecological range. However, it can extend beyond this into more open dry deciduous and dry thorn forests using riverine habitats or riverine type of microhabitats that exist along the streams. The riverine/stream microhabitats also act as corridors between two patches of optimal habitats besides being habitats at some places. However, anthropogenic pressure and developmental activities have cut-off such corridors resulting in isolation of squirrel population like the one found along the Avarahalla stream in Mudumalai. Overall, the distribution patterns of the species observed in the sanctuary suggest that canopy contiguity is the major factor influencing the giant squirrel distribution as reported elsewhere (Hall 1991; Ramachandran 1992; Rout \& Swain 2005).

Population density: A total of 55 sightings were made, with a mean group size of 1.16 squirrels/ sighting across $199.3 \mathrm{~km}$, amounting to a mean density of 2.9 individuals $/ \mathrm{km}^{2}$ (LCL 2.5 squirrels $/ \mathrm{km}^{2}$ and UCL 3.2 squirrels $/ \mathrm{km}^{2}$ ) (Table 1). Sampling covered large areas like dry thorn forests along the eastern side of the sanctuary and semi-open canopied woodlands in parts of the northern side of the sanctuary, which do not have squirrels or support low density, resulting in lower overall densities.

The density of giant squirrel estimated (2.9 squirrels/ $\mathrm{km}^{2}$ ) in Mudumalai Sanctuary is comparable to that of Bandipur Tiger Reserve (2.4 giant squirrels $/ \mathrm{km}^{2}$ ) (Jathana et al. 2008), an adjoining park in the landscape with similar habitat conditions. However, our estimate is lower than the ecological densities estimated for the parts of Bhadra Tiger Reserve (Muthodi: 10.2 squirrels/ $\mathrm{km}^{2}$ and Lakkavalli: 12.3 squirrels $/ \mathrm{km}^{2}$ ) (Jathana et al. 2008) with deciduous habitats dominating the sampling areas. Borges et al. (1998) report densities as high as 
Table 1. Density of Indian Giant Squirrel estimated in Mudumalai Wildlife Sanctuary using line transect method and DISTANCE software

\begin{tabular}{|l|l|}
\hline Parameters & Values \\
\hline Effort (distance in $\mathrm{km}$ ) & 199.3 \\
\hline Number of cluster (group) detections $(n)$ & 55 \\
\hline Encounter rate (squirrel clusters/km) & 0.28 \\
\hline Cluster density/ km² SE & $2.58 \pm 0.171$ \\
\hline Cluster density \% co-efficient of variation & 6.97 \\
\hline Cluster density 95\% Cl lower-upper & $2.14-2.83$ \\
\hline Model selected & Uniform \\
\hline Adjustment & Cosine 1 \\
\hline Minimum AIC & 487.9 \\
\hline Mean cluster size \pm SE & $1.16 \pm 0.050$ \\
\hline Squirrel density / km² \pm SE & $2.9 \pm 0.313$ \\
\hline Squirrel density $95 \%$ Cl lower-upper & $2.5-3.2$ \\
\hline
\end{tabular}

$12-66 / \mathrm{km}^{2}$, respectively, in the semievergreen and evergreen habitats of Bimashankar Wildlife Sanctuary, Maharashtra. These are, however, ecological densities and a true comparison cannot be made with the present study. The findings of the present study and the earlier studies suggest that habitat with primary forests (semievergreen and evergreen) with better canopy cover and more tree species density and diversity is likely to support higher density of giant squirrels than secondary forests (deciduous and dry thorn).

Activity pattern: A total of 24,098 minutes of observation were made using focal animal sampling to study the activity budget of the giant squirrel (Fig. 2). Feeding (47\%) and resting (47\%) together accounted for $94 \%$ of the squirrel's daily activity. Time spent on movement (other than while feeding) accounted for $5.1 \%$ of the time and all other activities together accounted for just $1.2 \%$ of the squirrel's daily activity. Similarly, giant squirrels in the deciduous forests of Parambikulam Wildlife Sanctuary spend major part of their day time on feeding (49.6\%) and resting (28.2\%) (Ramachandran 1992). Borges et al. (1998) also recorded feeding and resting as the major activities accounting for over $75 \%$ of the squirrel's daily activity. The lower time on feeding and resting reported by Borges et al. (1998) compared to the present study could be due to (i) differences in scoring (defining) movement during observation, as we have treated movements within a tree while feeding as feeding as well as (ii) spatial difference in quality of food sources

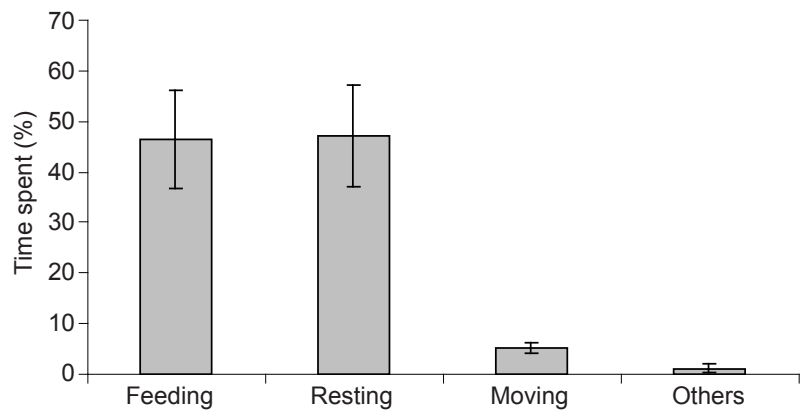

Figure 2. Percent of time spent on different activities by Indian Giant Squirrel in Mudumalai Wildlife Sanctuary (error bar = standard deviation, in activities others include inter- and intra-specific behaviours, drinking, urination, defecation and nest building)

available on which the squirrels mostly feeds on.

\section{Feeding}

Diet species composition: Data on feeding on various food plants and their parts eaten were arrived from 24,098 focal sampling observations. The squirrel in the sanctuary was observed to use 25 species of plants, mostly tree, except Lantana camara and Loranthus sp. (Appendix I). The contribution of various plant species to the diet of squirrel varied from more than $41 \%$ to less than $0.1 \%$. Despite feeding on 25 species, the bulk of the diet $(83.45 \%)$ came from only five species while another seven species contributed $11.72 \%$ (Table 2$)$. The remaining 14 species $(4.83 \%$ of diet) contributed only marginally to the overall diet of giant squirrels. Teak was the most significant contributor to the diet of squirrel and formed $40.9 \%$ of the overall diet. Terminalia tomentosa, Grewia tillifolia and Lagerstoemia lanceolata accounted for $16.5,14.5$ and $5.7 \%$ of the squirrel's diet respectively. The parasitic epiphyte Loranthus sp. was the only major non-tree species, which accounted for $5.9 \%$ of its diet. All other species individually contributed less than $3 \%$ of the squirrel's diet. $R$. indica are known to feed intensively (around 80\%) on few species over a large variety of food plants, both in the deciduous (Ramachandran 1992) and evergreen (Borges et al. 1998) forests of southern India.

Plant part selection: The giant squirrel feeds on seeds, fruits, flowers, bark, petiole and leaves from different plants (Table 2). Seeds (31.3\%) and tree bark $(30.4 \%)$ are two major components of its diet accounting together for $61 \%$ of the diet. Flowers and fruits contributed nearly $20 \%$, while leaves and 
Table 2. Percent contribution of various plant species and their parts to the diet of Indian Giant Squirrel in Mudumalai Wildlife Sanctuary

\begin{tabular}{|l|c|c|c|c|c|c|c|}
\hline \multirow{2}{*}{ Plant species } & \multicolumn{7}{|c|}{ Parts eaten (\%) } \\
\cline { 2 - 8 } & Seed & Bark & Petiole & Leaf & Flower & Fruit & Total \\
\hline Tectona grandis & 31.12 & 4.8 & 2.47 & 0.63 & 1.86 & - & 40.88 \\
\hline Terminalia tomentosa & 0.13 & 6.73 & 4.65 & 3.13 & 0.92 & 0.93 & 16.49 \\
\hline Grewia tilifolia & - & 8.38 & 0.45 & 1.75 & 1.08 & 2.84 & 14.5 \\
\hline Loranthus sp. & - & 0.24 & 0.91 & 0.39 & 2.97 & 1.38 & 5.89 \\
\hline Lagerstroemia lanceolata & - & 2.85 & 1.1 & 0.89 & 0.85 & - & 5.69 \\
\hline Bombax ceiba & - & 0.88 & - & 0.35 & 1.1 & - & 2.33 \\
\hline Anogiessus latifolia & - & 2.0 & - & - & - & - & 2.0 \\
\hline Randia dumetorum & - & - & - & - & - & 1.6 & 1.6 \\
\hline Oogina oginensis & - & 0.88 & - & - & 0.68 & - & 1.56 \\
\hline Mangifera indica & - & - & - & 0.51 & 0.15 & 0.79 & 1.45 \\
\hline Terminalia bellerica & - & 1.29 & - & - & - & 0.15 & 1.44 \\
\hline Ficus sp. & $\mathbf{3 1 . 2 5}$ & $\mathbf{3 0 . 3 9}$ & $\mathbf{1 0 . 0 4}$ & $\mathbf{8 . 6 7}$ & $\mathbf{1 0 . 1 8}$ & $\mathbf{9 . 3 9}$ & $\mathbf{9 9 . 9 2}$ \\
\hline Others (13 spp.) & & - & - & - & - & 1.26 & 1.26 \\
\hline Total & - & 2.34 & 0.46 & 1.02 & 0.57 & 0.44 & 4.83 \\
\hline
\end{tabular}

petiole accounted for nearly $19 \%$. Seeds and bark are generally available almost round the year and therefore they form the bulk of the squirrel's diet and these could also be due to the high calorific content in these plant parts as reported elsewhere for the same species (Borges 1989) and North American tree squirrel Tamiasciurus hudsonicus and T. douglassi (Smith 1968). Flowers and fruits are however very seasonal and are consumed intensively when available. However, their restricted seasonal availability results in lower contribution to the annual (overall) diet even when their seasonal contribution is extremely high. Leaves and petioles, on the other hand, are available for much longer duration but their contribution to the overall diet is lower depending on the growth stage at which squirrels prefer them and also the seasonality of some deciduous species. Similar to the present results, seeds and barks form the major part of the giant squirrels diet reported earlier for Mudumalai: the present study area (Thorington \& Cifelli 1989) and elsewhere in southern India (Ramachandran 1992). Ramachandran (1992) states that the species is basically a seed feeder, switching to leaves and bark when seeds are not available. In contrast to the present study, Borges et al. (1998) report that leaves (immature and mature) formed over $62 \%$ of the diet in an evergreen forest. As mentioned above, in the present study, the deciduous nature of the habitat would make the availability of leaves seasonal and thereby reduce their overall contribution to the diet. In the evergreen habitat, bark formed only $6.5 \%$ of the diet (Borges et al. 1998), and fruits and flowers over $31 \%$. This could be due to the extended availability of flowers and fruits in evergreen forests (Borges et al. 1998) than deciduous forest. This allows squirrels to increase the intake of these food items and reduce that of bark, which may not be nutritionally as rich as flower and fruits. The higher dependence on bark indicates the squirrel's adaptation to survive in a habitat that does not provide the most preferred resources throughout the year. Higher dependence of $R$. indica on low quality fibrous food have been reported elsewhere in southern India (Borges 1992, 1993) Further, data on the seasonal feeding and use of plant parts, as shown in Desai et al. (1999), give a better insight into these aspects.

Nesting behaviour and abundance: The giant squirrel constructs globular nests or dreys using leaves and twigs, multiple in numbers within their home range. In total, 83 nests were located along $54.2 \mathrm{~km}$ transects, giving an encounter rate of 1.5 nests $/ \mathrm{km}$ of transects and the encounter rate varied in different habitats $(1.8,1.5$ and 1.0 nests $/ \mathrm{km}$, respectively, in the moist, and dry deciduous and dry thorn forests). The higher abundance of nest in moist deciduous forest compared to dry deciduous and thorn dry forest could 
Table 3. Mean measures of various parameters studied for nest and non-nest trees and their statistical significance

\begin{tabular}{|l|c|c|c|}
\hline Parameters studied & Nesting tree species $(\mathbf{n}=\mathbf{8 3})$ & Non-nesting tree species $(\mathbf{n}=\mathbf{2 8 0})$ & Man-Whitney U test \\
\hline Girth at breast height $(\mathrm{cm})$ & 233.1 & 170.2 & $\mathrm{u}=6697, \mathrm{p}=<0.001$ \\
\hline Tree height $(\mathrm{m})$ & 18.8 & 16.5 & $\mathrm{u}=9079, \mathrm{p}=<0.001$ \\
\hline Canopy height $(\mathrm{m})$ & 10.6 & 8.7 & $\mathrm{u}=8452, \mathrm{p}=<0.001$ \\
\hline Number of branches & 4.0 & 3.1 & $\mathrm{u}=8483, \mathrm{p}=<0.01$ \\
\hline Canopy contiguity $(\%)$ & 88.2 & 77.7 & $\mathrm{u}=8721, \mathrm{p}=<0.001$ \\
\hline
\end{tabular}

be attributed to better canopy contiguity in the former habitat than the latter as reported elsewhere (Srinivas et al. 2008).

Nest tree selection: Of the 33 tree species recorded along transects, the squirrel preferred only 15 species for nest building (Appendix I). A statistical analysis performed to see whether the selection of nest trees was in proportion to their availability (in the same habitat) showed a significant difference $\left(\chi^{2}=39.26, \mathrm{df}\right.$ $=14, \mathrm{p}<0.001)$, as some species were selected more often than expected, while others were selected less indicating preference for a few species. Schliechera oleosa was the most preferred tree species for nesting followed by Mangifera indica. Although T. grandis had 15 nests, its use was in proportion to its abundance or availability in the forest. The high preference for $M$. indica and S. oleosa, which are found mostly along rivers and streams, could be due to their dense canopy cover, and higher canopy height and contiguity that could offer better protection and escape from predators.

Nest tree characters: Squirrels prefer trees with large gbh and taller height classes (both tree and its canopy) and number of branches (Table 3 ) for nest building. The nesting trees were significantly larger in all characteristics than the non-nesting ones sampled in the population. Such biased selection towards mature trees with greater canopy contiguity could facilitate easy movement to and from the nest in all directions, a major advantage to escape from predators and to move to other parts of the home range for foraging and other activities as reported by Ramachandran (1992).

Nest characters: Nests are not built on trees randomly but mostly at the highest point on the tree that offered a good location including cover that provide maximum security. Majority of the nests (68.7\%) were located at greater than $15 \mathrm{~m}$ of the tree height, while another $26.5 \%$ were between 10 and $15 \mathrm{~m}$ of the tree height. Only $4.8 \%$ nests were located at between 5 and $10 \mathrm{~m}$ of the tree height and in all the cases over $70 \%$ of the tree height. These results coupled with the results of nest tree characters show that the squirrels prefer the largest trees available and highest locations on the trees within their home range to build their nests. The selection is however strongly influenced by tree species and their physical characteristics including canopy contiguity as reported elsewhere (Datta \& Goyal 1996) for the species.

Home range: The duration of sampling was not equal among all the four squirrels observed in four habitats. Data on the home range size of squirrels in the dry deciduous stream, teak plantation and riverine habitats were based on eight months duration each. While data for the squirrels in moist deciduous forest represents five months, as we had to change the focal animal in this habitat due to difficulty of accessing the location from our base camp during rainy season. The home range size varied from 0.8 to 1.7 ha, with squirrels in the moist deciduous (1.7ha) and teak plantation (1.6ha) having larger home range than those in the riverine (1.1ha) and dry deciduous streams $(0.8$ ha). The mean home range size was $1.3 \mathrm{ha}(\mathrm{SD}=0.415$, $\mathrm{n}=4)$. Considering the 5-8 months of observation and just 1-2 days of ranging data per month, the range size estimated should be considered as minimum. However, the mean home range size estimated in this study is comparable to that reported by Borges (1989) (approximately 1ha), Borges et al. (1998) (1.91ha $\mathrm{n}=11$ ), but much smaller than that reported by Ramachandran (1988) (13.4ha). Though the squirrel is considered territorial, there have been instances of squirrels from the adjoining areas intruding into the home ranges of the focal study animals observed during direct observations indicating some degree of overlap in space among neighbouring individuals. In addition, many squirrels sharing a single food resource (i.e. $M$. indica tree while in fruiting stage) was also observed, even though there were also signs of aggression. 


\section{Conservation implications}

The data on feeding showed that the giant squirrel is largely dependent on a few species of trees for the bulk of its diet. This could be due to the paucity of suitable food species (diversity and richness). There is a need to recognize the fact that a diverse natural habitat with mature tree is important for giant squirrel not only for feeding but also for nesting and movement. Modification of habitat through monoculture plantation and or selective felling of mature trees for timber would lead to a decline in habitat quality. However, at present, these do not apply to protected areas in India; such practices in the past to some extent depleted the quality of habitats for the giant squirrels in the sanctuary. Supplementing or enriching the habitat through planting of preferred tree species is not suggested, as this may not be cost effective but fire protection may be strengthened as frequent fires can retard the regeneration of many natural species depleted by past exploitation of these forests.

The importance of riverine habitats and similar microhabitats associated with streams for facilitating giant squirrel distribution and movement in marginal, patchy and fragmented habitats has been highlighted. It must also be recognized that the plant species associated within these macro/microhabitats are more similar to evergreen/moist deciduous species and they may not be as fire resistant as dry deciduous species. Such species when continuously exposed to annual fire will not be able to regenerate successfully resulting in depletion of the riverine species and breaks in canopy continuity due to gradual change in vegetation composition. Therefore, it is essential to recognize the vital role of such small habitats and extend special protection to them.

Similarly, there is a need to ensure the canopy continuity of the Moyar riverine habitats between Kargudy and Teppakadu with adjoining habitats, where interstate highway has broken the canopy contiguity, which is impeding the squirrels' access to the optimal resource patches.

\section{REFERENCES}

Abdulali, H. \& J.C. Daniel (1952). Race of the Giant Squirrel (Ratufa indica). Journal of the Bombay Natural History Society 50: 467-474

Agarwal, V.C. \& S. Chakraborty (1979). Catalogue of mammals in the Zoological Survey of India, Rodentia, Part I - Sciuridae. Records of Zoological Survey of India 74: 333-481.

Altmann, J. (1974). Observational study of behaviour sampling method. Behaviour 49: 227-265

Baskaran, N. (1998). Ranging and resource utilization by Asian Elephants (Elephas maximus) in Nilgiri Biosphere Reserve, South India. PhD Thesis, Bharathidasan University, Tiruchirappalli, India, iii+138pp.

Borges, R. (1989). Resource heterogeneity and the foraging ecology of the Malabar Giant Squirrel (Ratufa indica). PhD Thesis, University of Miami, Florida.

Borges, R.M. (1992). A nutritional analysis of foraging in the Malabar Giant Squirrel (Ratufa indica). Biological Journal of the Linnean Society 47: 1-21.

Borges, R.M. (1993). Figs and Malabar Giant Squirrels in two tropical forests in India. Biotropica 25: 183-190.

Borges, R., R.S. Mali \& H. Somanathan (1998). The status, ecology and conservation of the Malabar Giant Squirrel Ratufa indica. Final report, Wildlife Institute of India.

Buckland, S.T., D.R. Anderson, K.P. Burnham, J.L. Laake, D.L. Borchers \& L. Thomas (2004). Advanced Distance Sampling. Oxford University Press, Oxford, United Kingdom, 414pp.

Burnham, K.P., D.R. Anderson \& J.L. Lake (1980). Estimation of density from line transects sampling of biological populations. Wildlife Monograph 72: 1-72

Corbet, G.B. \& J.E. Hill (1992). The mammals of the IndoMalayan region. Natural History Museum Publications, Oxford University Press, Oxford, England, vii+488pp.

Datta, A. \& S.P. Goyal. (1996). Comparison of forest structure and use by the Indian Giant Squirrel (Ratufa indica) in two riverine forests of Central India. Biotropica 28(3): 394 399.

Desai A.A., N. Baskaran, S. Venkatesan \& J. Mani (1999). Ecology of the Malabar Giant Squirrel (Ratufa indica) in Mudumalai Wildlife Sanctuary and National Parks. Technical Report. Bombay Natural History Society and Tamil Nadu Forest Department.

Goodman, L. (1960). On the Exact Variance of Products. Journal of the American Statistical Association 55: 708713.

Hall, J.H. (1991). A field study of the Kaibab Squirrel in Grand Canyon Park. Wildlife Monograph 75: 54pp.

Indian Wildlife Act (1972). The Indian Wildlife Protection Act, 1972, (as amended up to 1993). <http://envfor.nic. in/legis/wildlife/wildlife1.html $>$ Downloaded on 27 May 2010.

Jathana, D., N.S. Kumar \& K.U. Karanth (2008). Measuring Indian giant squirrel (Ratufa indica) abundance in southern 
Appendix 1. Number of plant species eaten by squirrel recorded during feeding observations and tree species recorded in transect during nest survey ( $\mathrm{Y}$ indicates the species eaten by squirrel)

\begin{tabular}{|c|c|c|c|c|}
\hline & \multirow{2}{*}{ Plant species } & \multirow{2}{*}{$\begin{array}{l}\text { Plant species } \\
\text { eaten }(n=25)\end{array}$} & \multicolumn{2}{|c|}{$\begin{array}{l}\text { Number of tree species recorded in transect during nest } \\
\text { survey }(n=31)\end{array}$} \\
\hline & & & $\begin{array}{l}\text { \# of individual recorded } \\
\qquad(\mathrm{n}=412)\end{array}$ & $\begin{array}{l}\% \text { of individuals with nest } \\
\qquad(n=83)\end{array}$ \\
\hline 1 & Aleodendron glocum & - & 1 & 0 \\
\hline 2 & Anogiessus latifolia & $\mathrm{Y}$ & 45 & 4.4 \\
\hline 3 & Bambusa arundinacae & $\mathrm{Y}$ & 2 & 0 \\
\hline 4 & Bauhinia recemosa & - & - & - \\
\hline 5 & Bombax ceiba & $\mathrm{Y}$ & 2 & 0 \\
\hline 6 & Butea monosperma & - & 3 & 0 \\
\hline 7 & Cassia fistula & $\mathrm{Y}$ & - & - \\
\hline 8 & Cordia domestica & $\mathrm{Y}$ & - & - \\
\hline 9 & Dalbergia latifolia & $\mathrm{Y}$ & 12 & 0 \\
\hline 10 & Erthroxylon monogynum & - & - & - \\
\hline 11 & Ficus sp. & $\mathrm{Y}$ & 2 & 0 \\
\hline 12 & Garuga pinnata & $\mathrm{Y}$ & 4 & 0 \\
\hline 13 & Gmelina arborea & - & 1 & 0 \\
\hline 14 & Grewia tillifolia & $\mathrm{Y}$ & 18 & 22.2 \\
\hline 15 & Hymenodictylon sp. & - & - & - \\
\hline 16 & Kydia calycina & - & 1 & 0 \\
\hline 17 & Lagerstroemia lanceolata & $\mathrm{Y}$ & 16 & 0 \\
\hline 18 & Lantana camera & $\mathrm{Y}$ & - & - \\
\hline 19 & Loranthus sp. & $\mathrm{Y}$ & - & - \\
\hline 20 & Mangifera indica & $\mathrm{Y}$ & $\underline{54}$ & $\underline{35.2}$ \\
\hline 21 & Mitragyna parvifolia & $\mathrm{Y}$ & 8 & 25.0 \\
\hline 22 & Oogina oginensis & $\mathrm{Y}$ & 1 & 0 \\
\hline 23 & Ouginia oojeinensis & - & 1 & 0 \\
\hline 24 & Phyllanthus emblica & Y & 10 & 0 \\
\hline 25 & Pterocarpus marsupium & $\mathrm{Y}$ & 1 & 100 \\
\hline 26 & Pungamia pinnata & - & 9 & 0 \\
\hline 27 & Radermachera xylocarpa & - & 3 & 0 \\
\hline 28 & Randia dumetorum & $\mathrm{Y}$ & 2 & 50.0 \\
\hline 29 & Schelichera oleosa & Y & $\underline{26}$ & $\underline{65.4}$ \\
\hline 30 & Stereospermum chelonoides & - & 11 & 18.2 \\
\hline 31 & Syzygium cumini & $\mathrm{Y}$ & 25 & 24.0 \\
\hline 32 & Tamarindus indica & - & 9 & 33.3 \\
\hline 33 & Tectona grandis & $\mathrm{Y}$ & 60 & 25.0 \\
\hline 34 & Terminala tomentosa & $\mathrm{Y}$ & 63 & 11.1 \\
\hline 35 & Terminalia bellerica & $\mathrm{Y}$ & 11 & 18.2 \\
\hline 36 & Terminalia chebula & $\mathrm{Y}$ & - & - \\
\hline 37 & Terminalia paniculata & - & 9 & 11.1 \\
\hline 38 & Vitex sp. & $\mathrm{Y}$ & 1 & 0 \\
\hline 39 & Unidentified sp. & - & 1 & 100 \\
\hline
\end{tabular}


India using distance sampling. Special editing: Arboreal squirrel. Current Science 95(7): 885-888.

Jennrich, R.I. \& F.B. Turner (1969).Measurements of non-circular home ranges. Journal of Theoretical Biology 22: 227-237.

Kumara H.N. \& M. Singh (2006). Distribution and relative abundance of giant squirrels and flying squirrels in Karnataka, India. Mammalia 70: 40-47.

Rajamani, N., S. Molur \& P.O. Nameer (2009). Ratufa indica. In: IUCN 2011. IUCN Red List of Threatened Species. Version 2011.1. <www.iucnredlist.org>. Downloaded on 12 July 2011.

Ramachandran, K.K. (1988). Ecology and behaviour of Malabar Giant Squirrel Ratufa indica maxima (Schreber) 1788. Report of the Project Wild 04/83. Division of Wildlife Biology, Kerala Forest Research Institute, Peechi, Kerala, 47pp.

Ramachandran, K.K. (1992). Certain aspects of ecology and behaviour of Malabar Giant Squirrel Ratufa indica (Schreber). PhD Thesis. Department of Zoology, University of Kerala, 191pp.

Rout, S.D. \& D. Swain (2005). Status of Giant Squirrel (Ratfa indica) in Similipal Tiger Reserve, Orissa, India. Indian Forester 131(10): 1363-1372.

Smith, C.C. (1968). The adaptive nature if the social organization in the genus of tree squirrels, Tamiasciurus. Ecological Monograph 38: 31-63.

Srinivas, V., P.D. Venugopal \& S. Ram (2008). Site occupancy of the Indian Giant Squirrel Ratufa indica (Erxleben) in Kalakad-Mundanthurai Tiger Reserve, Tamil Nadu, India. Special editing: Arboreal squirrel. Current Science 95(7): 889-894.

Thomas, L., J.L. Laake, S. Strindberg, F.F.C. Marques, S.T. Buckland, D.L. Borchers, D.R. Anderson, K.P. Burnham, S.L. Hedley, J.H. Pollard, J.R.B. Bishop, \& T.A. Marques (2005). DISTANCE, version 5.0, beta 5. Research Unit for Wildlife Population Assessment, University of St. Andrews, United Kingdom. [Online] Available at www.ruwpa.st-and.ac.uk/distance/.

Thorington, R.W. Jr. \& R.L. Cifelli (1989). The usual significance of the giant squirrels (Ratufa), pp. 212-219. In: Daniel, J.C. \& J.S. Serrao (eds.). Conservation in Developing Countries: Problem and Prospects. Proceeding of the Centenary Seminar of the Bombay Natural History Society. Oxford University Press.
Author Detail: N. BASKARAN is presently a senior scientist at the Asian Nature Conservation Foundation, Indian Institute of Science, Bangalore. He has two decades of research experience in studying behavioural ecology of an umbrella species 'the Asian elephant' across Eastern, and Western Ghats and Eastern Himalayas. In addition, experienced in assessing biodiversity, habitats and behavioural ecology of mammalian species such as Sloth Bear, Grizzled Giant Squirrel and Four-horned Antelope.

S. VeNKATESAN is a wildlife biologist, completed his $\mathrm{PhD}$ in Marine Biology and continue working on marine organism research and conservation.

$\mathrm{J}$. MANI is a wildlife biologist but has shifted to non-wildlife field since 1999.

Sanjay K. SRIVAstava is presently a Cheif Conservator of Forests in Tamil Nadu. He has been specilizing on Geographical Information System and Remote Sensing for the past ten years.

AJAYA. DESAI is a wildlife biologist specialized on Asian Elephants through studies on behaviour, ecology and conservation over the past three decades. He consults for the conservation projects in Asian Elephant range counties. He is the co-chair of the IUCN SSC Asian Elephant Specialist Group, and Steering Committee Member of Project Elephant Govt. of India.

Justification for delayed publication: Though the data was collected over a decade back (1998-2000), the findings are still important, as there exist no detailed published data on the ecology and behaviour of the species from Nilgiri Biosphere Reserve, which are essential for the conservation planning of the species -N. Baskaran. 